\title{
Distribusi Data dan Informasi JKN-KIS PBI di Desa Cintaratu Kabupaten Pangandaran
}

\author{
Data and Information Distribution of JKN-KIS PBI in Cintaratu Village, \\ Pangandaran Regency
}

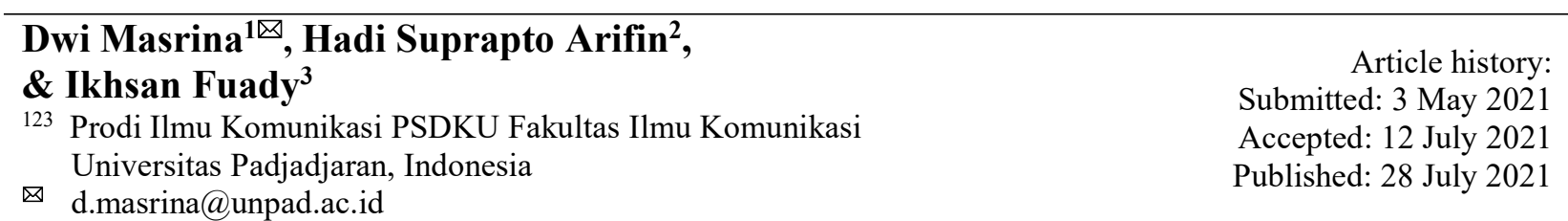

\begin{abstract}
Community service activities in Cintaratu Pangandaran Village were carried out as an initial program to find out and map the things needed by people of Cintaratu Village in terms of health information, especially information about JKN-KIS PBI (Jaminan Kesehatan NasionalKartu Indonesia Sehat-Penerima Bantuan Iuran). Researchers want to see how information related to JKN-KIS PBI is obtained and understood by the people. This activity was carried out for about four weeks using three different methods, namely the survey method, focus group discussion (FGD), and observation. The results of this community service showed that the distribution of information and data in Cintaratu Village regarding JKN-KIS PBI is generally less transparent. The population data used by the central government as the basis for determining aid has been out of date so that aid has not been well-targeted. The people of Cintaratu Village got health information about JKN-KIS PBI by relying on opinion leaders, namely village officers, midwives, and health cadres.
\end{abstract}

Keywords: Cintaratu Pangandaran; health service; JKN-KIS PBI; opinion leader.

Abstrak: Kegiatan pengabdian masyarakat di Desa Cintaratu Pangandaran dilakukan sebagai program awal untuk mengetahui dan memetakan hal-hal yang dibutuhkan oleh masyarakat desa khususnya informasi seputar JKN-KIS PBI (Jaminan Kesehatan Nasional-Kartu Indonesia SehatPenerima Bantuan Iuran). Peneliti ingin melihat bagaimana informasi-informasi terkait JKN-KIS PBI didapat dan dipahami oleh masyarakat Desa Cintaratu. Kegiatan ini dilaksanakan selama empat pekan menggunakan tiga metode yang berbeda yaitu metode survei, focus group discussion ( $F G D$ ) dan observasi. Hasil dari pengabdian masyarakat ini menunjukkan bahwa distribusi informasi di Desa Cintaratu seputar JKN-KIS PBI secara umum kurang transparan. Data penduduk yang digunakan pemerintah pusat sebagai dasar penetapan bantuan telah kedaluwarsa sehingga bantuan menjadi tidak tepat sasaran. Masyarakat Desa Cintaratu mendapatkan informasi kesehatan seputar JKN-KIS PBI mengandalkan opinion leader yaitu aparat desa/dusun/RW/RT, bidan dan kader kesehatan.

Kata Kunci: Cintaratu Pangandaran; JKN-KIS PBI; layanan kesehatan; pemuka pendapat. 


\section{Pendahuluan}

Tanpa adanya kesehatan, manusia akan sulit untuk melaksanakan aktivitasnya setiap hari. Di dalam konstitusi World Health Organization Tahun 1948 disebutkan bahwa kesehatan adalah hak fundamental bagi setiap manusia, sebagaimana telah diratifikasi juga oleh Negara Indonesia. Dengan demikian, Pemerintah Indonesia pun memiliki peran penting dalam memenuhi hak setiap warga negaranya untuk sehat dan mendapatkan pelayanan kesehatan yang memadai (Ardinata, 2020).

Dalam laman web Kementerian Kesehatan Republik Indonesia, diketahui bahwa Indeks Pembangunan Kesehatan Manusia Indonesia pada tahun 2018 mengalami perbaikan dari tahun 2013. Perubahan capaian IPKM 2018 dan IPKM 2013 salah satunya terlihat pada peningkatan nilai minimum dan maksimum. Pada tahun 2013 nilai minimum IPKM Indonesia adalah 0,2169 meningkat menjadi 0,3469 pada tahun 2018. Sedangkan nilai maksimum IPKM yang pada tahun 2013 adalah 0,7325 meningkat menjadi 0,7470 pada tahun 2018 (Biro Komunikasi dan Pelayanan Masyarakat, 2019).

Sebagai sebuah negara yang berdaulat, Indonesia memiliki program kesehatan berbasis asuransi untuk memenuhi hak kesehatan warga negaranya. Program tersebut bernama Jaminan Kesehatan Nasional (JKN). Program ini dimaksudkan untuk menjamin kesehatan Warga Negara Indonesia. Namun demikian, program ini masih menjadi salah satu tantangan implementasi utama bagi penanganan masalah kesehatan di Indonesia. Tantangan ini terutama menyangkut pendirian lembaga, sistem dan prosedur agar pengoperasian JKN lebih efektif dan efisien (Mahendradhata et al., 2017).

Sebelum 1 Maret 2015, terdapat program perluasan JKN, yaitu KIS (Kartu Indonesia Sehat) yang merupakan program asuransi kesehatan yang dikelola oleh Badan Penyelenggara Jaminan Sosial (BPJS) Kesehatan untuk masyarakat miskin. Namun setelah tanggal tersebut, KIS dinyatakan sebagai kartu identitas seluruh peserta program JKN, bukan hanya dari kategori miskin atau tidak mampu, tetapi semua bagi warga Negara (Sekretariat Jenderal Kemenkes RI, 2018).

Selanjutnya sesuai kebijakan pemerintah, terdapat dua kelompok peserta JKN-KIS yaitu Penerima Bantuan Iuran (PBI) Jaminan Kesehatan dan Bukan PBI Jaminan Kesehatan. JKN-KIS PBI yaitu program kesehatan yang diperuntukkan bagi penduduk Indonesia yang menyandang status fakir miskin atau tidak mampu. Peserta PBI adalah fakir miskin yang ditetapkan oleh pemerintah dan diatur melalui Peraturan Pemerintah. Sedangkan JKN Non-PBI diwajibkan membayar iuran dengan besaran yang dapat dipilih dari kelas I, II, atau III. Peserta program ini terdiri dari pekerja penerima upah dan anggota keluarganya, pekerja bukan penerima upah dan anggota keluarganya, serta bukan pekerja dan anggota keluarganya (JKN.kemkes.go.id, n.d.).

Sampai Mei 2020, dari 220,6 juta peserta JKN-KIS, terdapat sekitar $60 \%$ peserta adalah peserta KIS yang dibiayai pemerintah melalui dana APBN dan APBD. Tepatnya, ada 96,8 juta penduduk miskin dan tidak mampu yang iuran JKN-KIS-nya ditanggung negara lewat APBN dan 37,3 juta penduduk yang ditanggung oleh APBD (Humas BPJS, 2020). Program kesehatan KIS diluncurkan bersamaan dengan KIP (Kartu Indonesia Pintar) pada tahun 2014. Sudah 6 tahun sejak KIS diluncurkan namun peneliti menemukan bahwa masih terdapat masyarakat yang belum memahami betul mengenai kehadiran kartu tersebut. 
Terkait dengan pelaksanaan program layanan kesehatan tersebut, khususnya di tingkat lokal daerah, tim peneliti tertarik untuk melakukan penelitian di Kabupaten Pangandaran, sebuah kabupaten yang merupakan pemekaran dari Kabupaten Ciamis, Provinsi Jawa Barat. Pada tahun 2014 tingkat harapan hidup di Pangandaran adalah 69,84 kemudian naik menjadi 70,84 pada tahun 2018 (Gambar 1). Peningkatan harapan hidup ini dipengaruhi oleh beberapa faktor, yaitu: akses pelayanan kesehatan yang semakin mudah bagi setiap kalangan, semakin baiknya perilaku hidup sehat masyarakat, semakin meningkatnya kondisi sosial-ekonomi masyarakat dan peningkatan dukungan terhadap kesehatan lingkungan. Selain itu, Pangandaran juga telah memiliki rumah sakit daerah yang baru saja diresmikan pada pertengahan tahun 2020. Dengan adanya dukungan dari berbagai pihak tersebut dan ditambah kesadaran masyarakat maka secara otomatis tingkat kehidupan yang sehat juga meningkat.

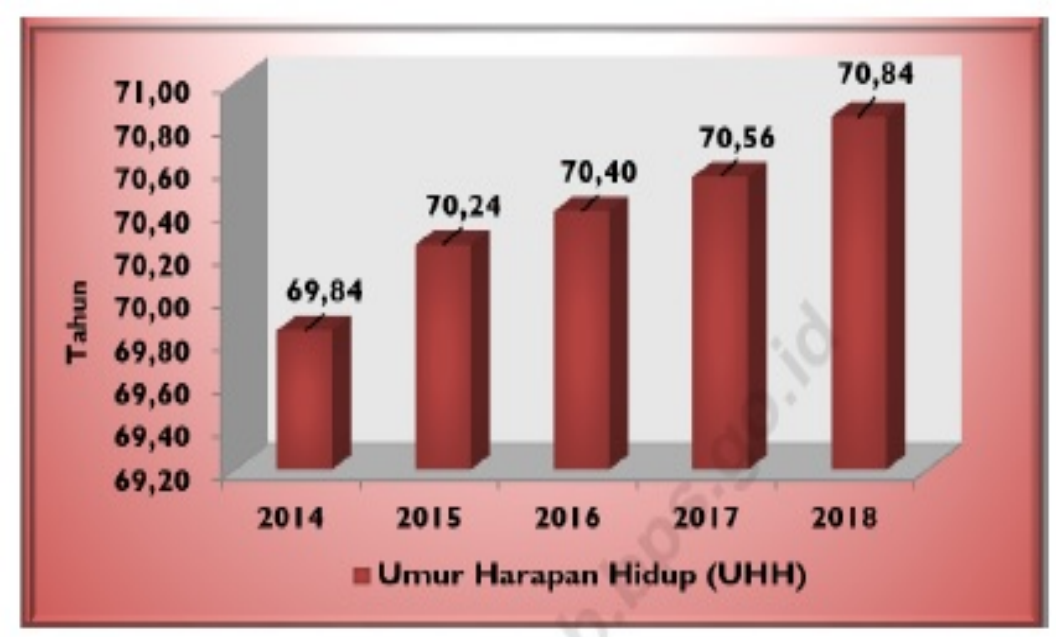

Gambar 1: Grafik Umur Harapan Hidup (UHH) di Kabupaten Pangandaran, 2014-2018 (Mustikasari, 2019)

Adapun berkaitan dengan aksesabilitas warga Pangandaran terhadap program layanan kesehatan, sebanyak 284.444 warga yang sudah terdaftar menjadi anggota BPJS (Enceng, 2019). Pemerintah kabupaten bahkan memiliki program kesehatan Kertawaluya, yaitu program bantuan jaminan kesehatan bagi warga kurang mampu. Walaupun begitu, kesehatan masih menjadi permasalahan yang cukup kompleks dan rumit dalam penyelesaiannya bagi Kabupaten Pangandaran. Perlu diketahui bahwa Pangandaran merupakan daerah resiko tinggi penularan HIV AIDS (Fuady et al., 2017), ditambah lagi angka harapan hidup Pangandaran masih berada di bawah rata-rata Provinsi Jawa Barat yaitu 72,66 (Mustikasari, 2019). Oleh karena itu, dalam upaya optimalisasi dan percepatan penyelesaian permasalahan kesehatan di Kabupaten Pangandaran, diperlukan kegiatan promosi kesehatan yang efektif melalui program JKN-KIS PBI. Akan tetapi sebelum melakukan kegiatan promosi kesehatan tersebut, perlu diketahui terlebih dahulu alur informasi dan karakteristik penggunaan media di masyarakat sebagaimana dilaksanakan melalui program kegiatan PKM ini.

Peneliti melakukan kegiatan PKM di Desa Cintaratu, yaitu sebuah desa yang berada di Kecamatan Parigi Kabupaten Pangandaran. Desa ini dipilih karena berada di dalam lingkar daerah PSDKU (Program Studi di luar Kampus Utama) Universitas Padjadjaran. Dalam hal sarana dan prasarana kesehatan, Cintaratu memiliki satu poskesdes dan lima posyandu. Cintaratu juga merupakan salah satu desa yang masyarakatnya menerima bantuan JKN-KIS PBI, namun 
ketersediaan informasi terkait JKN-KIS PBI masih minim, sehingga beberapa anggota masyarakat cenderung tidak memanfaatkan fasilitas kesehatan tersebut dan lebih memilih menggunakan pengobatan alternatif.

Masyarakat Desa Cintaratu yang sedang sakit seringkali melakukan pengobatan secara tradisional dengan obat-obatan herbal terlebih dahulu. Hal ini seringkali dilakukan sebagai pertolongan pertama kepada penderita. Pengobatan tradisional ini dijalankan oleh seorang dukun pengobatan yang sifatnya turun temurun dalam keluarga. Jika pengobatan tradisional tersebut tidak berhasil, warga akan mengunjungi poskesdes untuk mendapatkan layanan kesehatan lebih lanjut yang diperlukan. Pada kasus ibu hamil dan bayi, misalnya, sebagian kecil masyarakat Desa Cintaratu masih mempercayakan penanganan kepada dukun bersalin (atau biasa disebut paraji) ketimbang bidan. Berdasarkan informasi yang dihimpun melalui Bidan Desa Cintaratu, saat ini seringkali paraji akan didampingi oleh bidan ketika menangani proses persalinan ibu hamil atau ketika merawat bayi sakit.

Kegiatan PKM ini merupakan program awal yang dilakukan untuk mengetahui dan memetakan hal-hal yang dibutuhkan oleh Desa Cintaratu terutama dalam hal informasi kesehatan. Selama ini informasi kesehatan didistribusikan tanpa mempertimbangkan penggunaan jenis media yang akrab digunakan oleh masyarakat Desa Cintaratu. Oleh karena itu, tujuan dilakukannya kegiatan ini adalah untuk melihat alur distribusi informasi kesehatan khususnya tentang KIS, agar informasi tentang kesehatan khususnya tentang KIS dapat disalurkan secara lebih efektif dan efisien di masa depan. Peneliti mengambil ceruk pada distribusi informasi KIS untuk melihat bagaimana informasi seputar KIS tersebut didapat dan dipahami oleh masyarakat Desa Cintaratu. Pilihan dalam penggunaan media informasi juga sumber informasi lain dalam mengakses berita seputar JKN-KIS PBI akan dijelaskan lebih rinci di bagian pembahasan.

\section{Metode Pengabdian}

\section{Bentuk dan Tahapan}

Dalam kegiatan pengabdian masyarakat ini, demi mendapatkan data yang lebih padu dan komprehensif, maka peneliti menggunakan tiga metode pengumpulan data yang masing-masing metode digunakan untuk keperluan yang berbeda-beda. Ketiga metode tersebut adalah sebagai berikut:

\section{(1) Metode Survei}

Dalam metode survei, informasi dikumpulkan dari responden dengan menggunakan kuesioner. Metode ini digunakan di awal kegiatan pengabdian masyarakat untuk memperoleh data kasar berkaitan dengan sebaran informasi seputar KIS dan pemanfaatan media yang digunakan dalam mengakses informasi tersebut. Desa Cintaratu memiliki lima dusun yaitu: Panglanjan, Sukamanah, Gunungtiga, Cintasari dan Bontos. Dari kelima dusun tersebut peneliti menyebar 100 kuesioner secara acak di dusun Cintasari dan Bontos.

\section{(2) Focus Group Discussion (FGD)}

FGD adalah salah satu teknik pengumpulan data kualitatif yang didesain untuk memperoleh informasi keinginan, kebutuhan, sudut pandang, kepercayaan dan pengalaman peserta tentang suatu topik, dengan pengarahan dari seorang fasilitator atau moderator. FGD 
bertujuan untuk mengeksplorasi tema dengan lebih spesifik. Teknik ini digunakan untuk menghindari pemaknaan yang salah dari peneliti terhadap permasalahan yang diteliti (Paramita \& Kristiana, 2013).

Kegiatan menghimpun data melalui FGD dilaksanakan pada Kamis, 23 Januari 2020 bertempat di Balai Desa Cintaratu dan dihadiri oleh perangkat desa seperti Kepala Desa, Kepala Dusun, Ketua RT, Ketua RW, Bidan, Kader Kesehatan, dan pemuka masyarakat berjumlah 19 orang (Gambar 2). Kegiatan ini dilakukan untuk mengetahui seberapa dalam pemahaman masyarakat mengenai KIS serta distribusi informasi kesehatan lainnya pada masyarakat Desa Cintaratu.

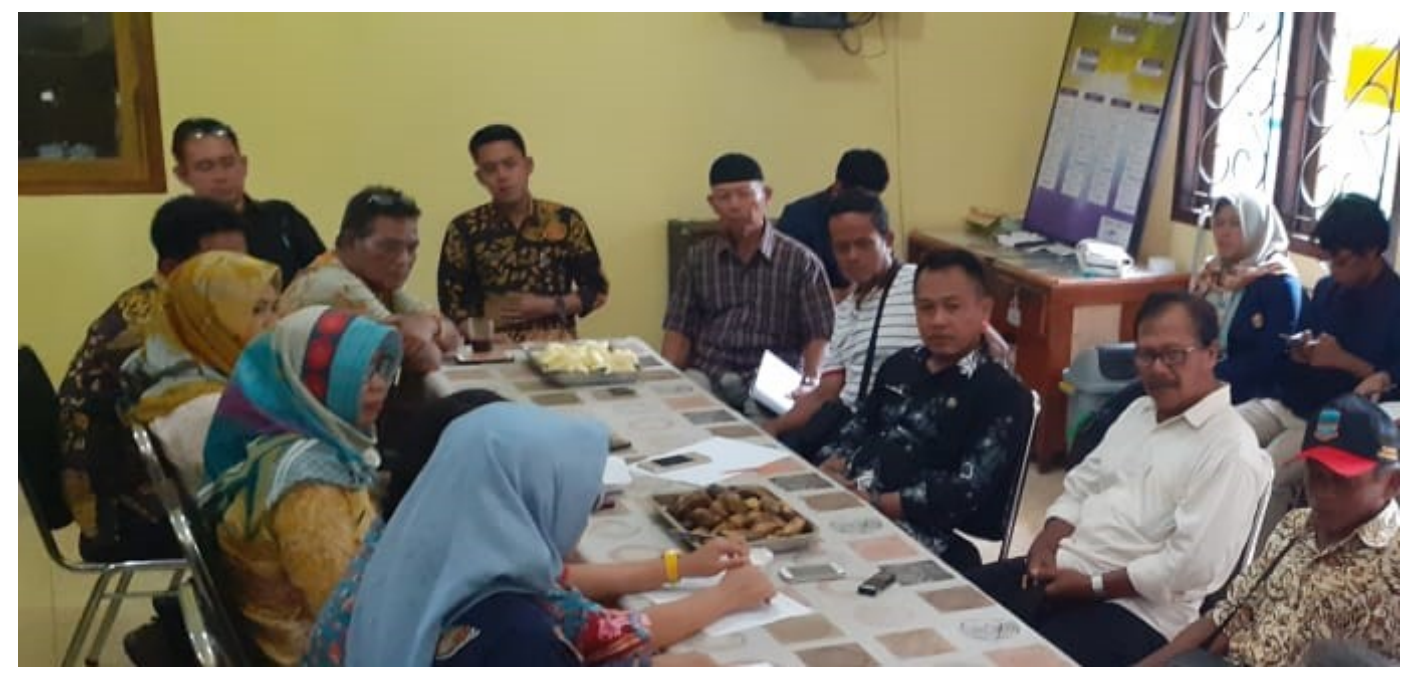

Gambar 2: Suasana Focus Group Discussion dengan warga Desa Cintaratu

\section{(3) Observasi}

Observasi merupakan proses pengamatan sistematis dari aktivitas manusia dan pengaturan fisik dimana kegiatan tersebut berlangsung secara terus menerus dari lokus aktivitas bersifat alami untuk menghasilkan fakta (Hasanah, 2017). Menurut Johnson (1975), setiap orang dapat melakukan observasi, dari bentuk sederhana sampai pada tingkatan observasi paling kompleks. Metode observasi yang digunakan pada setiap kegiatan penelitian bervariasi, tergantung pada setting, kebutuhan dan tujuan penelitian (Santana K, 2007). Observasi dilakukan selama 2 minggu, dimulai pada tanggal 19 Januari dan berakhir pada 1 Februari 2020. Kegiatan ini dilaksanakan sebagai salah satu cara untuk mendapatkan data yang lebih komprehensif mengenai distribusi informasi kesehatan khususnya KIS dan pilihan media yang digunakan oleh masyarakat Desa Cintaratu.

\section{Waktu Pelaksanaan}

Program ini secara keseluruhan dilaksanakan selama 1 bulan 3 hari, yaitu pada 9 Januari-12 Februari 2020 di Desa Cintaratu, Kecamatan Parigi, Kabupaten Pangandaran, Provinsi Jawa Barat. Kegiatan ini sengaja dilaksanakan di Desa Cintaratu berdasarkan letak Kampus Universitas Padjadjaran PSDKU Pangandaran yang berada di desa tersebut. 


\section{Hasil dan Pembahasan}

\section{Profil Kesehatan Desa Cintaratu}

Desa Cintaratu adalah salah satu desa yang berada di Kecamatan Parigi Kabupaten Pangandaran Propinsi Jawa Barat. Desa ini memiliki topografi daerah yang berbukit-bukit dengan luas wilayah 1.029 Ha. Mengenai demografi, Cintaratu memiliki 1.119 kepala keluarga dengan total penduduk adalah 3.421 jiwa. Dari sekian total penduduk terdiri dari 1.691 penduduk laki-laki dan 1.730 penduduk wanita.

Menyoal fasilitas kesehatan yang ada di desa, Cintaratu memiliki 1 poskesdes, 5 posyandu, 1 bidan praktik, dan 1 dokter praktik. Kegiatan posyandu diadakan sebulan sekali, baik posyandu balita maupun posyandu lansia. Bagi masyarakat Desa Cintaratu, posyandu dan poskesdes tidak hanya berfungsi sebagai tempat untuk mendapatkan layanan kesehatan, namun juga sebagai tempat untuk memperoleh informasi kesehatan termasuk informasi seputar KIS-PBI.

Tren pengobatan tradisional di Desa Cintaratu semakin menurun. Hal ini berkat peran bidan desa dan kader kesehatan yang berjumlah 50 orang di Desa Cintaratu dalam menyebarkan informasi kesehatan, masyarakat Desa Cintaratu semakin sadar kesehatan dan lebih memilih puskesmas sebagai pusat pelayanan kesehatan utama. Dari data sensus yang dikeluarkan oleh BPS Ciamis (Mustikasari, 2019), terjadi peningkatan drastis penduduk yang melakukan pengobatan ke klinik/praktik dokter bersama dan puskesmas/pustu (puskesmas pembantu), berturut-turut dari 12,63 persen dan 30,98 persen pada tahun 2017 menjadi 23,29 persen dan 35,10 persen pada tahun 2018. Sementara itu, penduduk yang berobat ke praktik pengobatan tradisional mengalami penurunan yaitu dari 3,02 persen pada tahun 2017 menjadi 0,70 persen pada tahun 2018 .

Persoalan kesehatan yang paling sering muncul di Desa Cintaratu adalah Kesehatan Ibu dan Anak (KIA). Terdapat beberapa kasus kekurangan gizi pada balita namun tidak sampai mengalami gizi buruk (stunting), sebagaimana informasi yang disampaikan oleh Tedi Setiadi, Kasi Pelayanan Pemerintahan Desa Cintaratu. Di desa ini masih dijalankan program seribu hari pertama kehidupan hingga angka kematian ibu dan anak berkurang mencapai angka 0 .

\section{Distribusi Data Peserta JKN-KIS PBI di Cintaratu}

Dinas Kesehatan Pangandaran tidak membahas secara detail bagaimana prosedur turunnya KISPBI. Berdasarkan informasi yang disampaikan oleh Sekretaris Desa Cintaratu, Konda Ruskonda, KIS-PBI dari pemerintah pusat bagi masyarakat Desa Cintaratu diterima melalui Pos Indonesia. Tidak ada instruksi untuk mengusulkan penerima JKN-KIS PBI sebelumnya sehingga pemerintah desa tidak mengetahui data penerima KIS PBI hingga JKN-KIS PBI tersebut diterima. Setelah KIS PBI diterima, baru diketahui bahwa data yang digunakan adalah data kedaluwarsa yang merupakan arsip desa pada tahun 1997. Dari data tersebut diketahui bahwa terdapat 100 keluarga yang berada di garis kemiskinan. Namun karena data yang dipakai telah kedaluwarsa, maka penerima JKN-KIS PBI kurang tepat sasaran. Telah ada beberapa penerima bantuan yang ternyata telah meninggal dunia dan beberapa lainnya memiliki tingkat ekonomi yang membaik.

Bantuan dari pemerintah pusat berupa JKN-KIS PBI sangat dibutuhkan oleh masyarakat Desa Cintaratu. Namun bantuan dirasa kurang tepat sasaran karena distribusi JKN-KIS yang tidak sesuai dengan data terbaru. Hal ini menyebabkan terjadinya miskomunikasi pada beberapa 
warga Desa Cintaratu. Terjadi pro-kontra seputar KIS-PBI, masyarakat merasa tidak puas dengan pendistribusian JKN-KIS PBI di Cintaratu. Beberapa warga bahkan merasa bahwa penerima bantuan pemerintah hanya berputar di orang-orang yang sama.

Bantuan dari pemerintah digunakan sebagai salah satu cara untuk mempercepat atau mengubah status miskin seseorang agar segera lebih mampu secara ekonomi (Rahman \& Herwiningsih, 2021). Namun yang terjadi, ketika masyarakat menerima bantuan pemerintah secara terus menerus maka menimbulkan efek candu. Ketika ekonomi penerima bantuan di Cintaratu membaik, ada penolakan ketika bantuan tersebut hendak dipindahkan kepada warga lain yang lebih membutuhkan, sehingga sempat terjadi kesalahpahaman di lingkungan Desa Cintaratu terkait bantuan pemerintah berupa JKN-KIS PBI.

Idealnya memang data yang akan digunakan sebagai acuan penerima bantuan bersifat bottom up atau data dihimpun dari bawah (masyarakat) dan disalurkan ke atas (pemerintah) (Marekan \& Ansori, 2019). Desa dapat melakukan sensus mandiri dan menggunakan data tersebut sebagai acuan untuk pengajuan penerima bantuan. Namun sayangnya, pada kasus yang terjadi di Cintaratu, ternyata distribusi data bersifat top-down saja. Tidak terjadi perputaran data awal yang baik, sehingga luaran yang terjadi di masyarakat Cintaratu juga tidak sesuai, yaitu banyak penerima bantuan yang salah sasaran.

\section{Akses Informasi Seputar JKN-KIS PBI di Cintaratu}

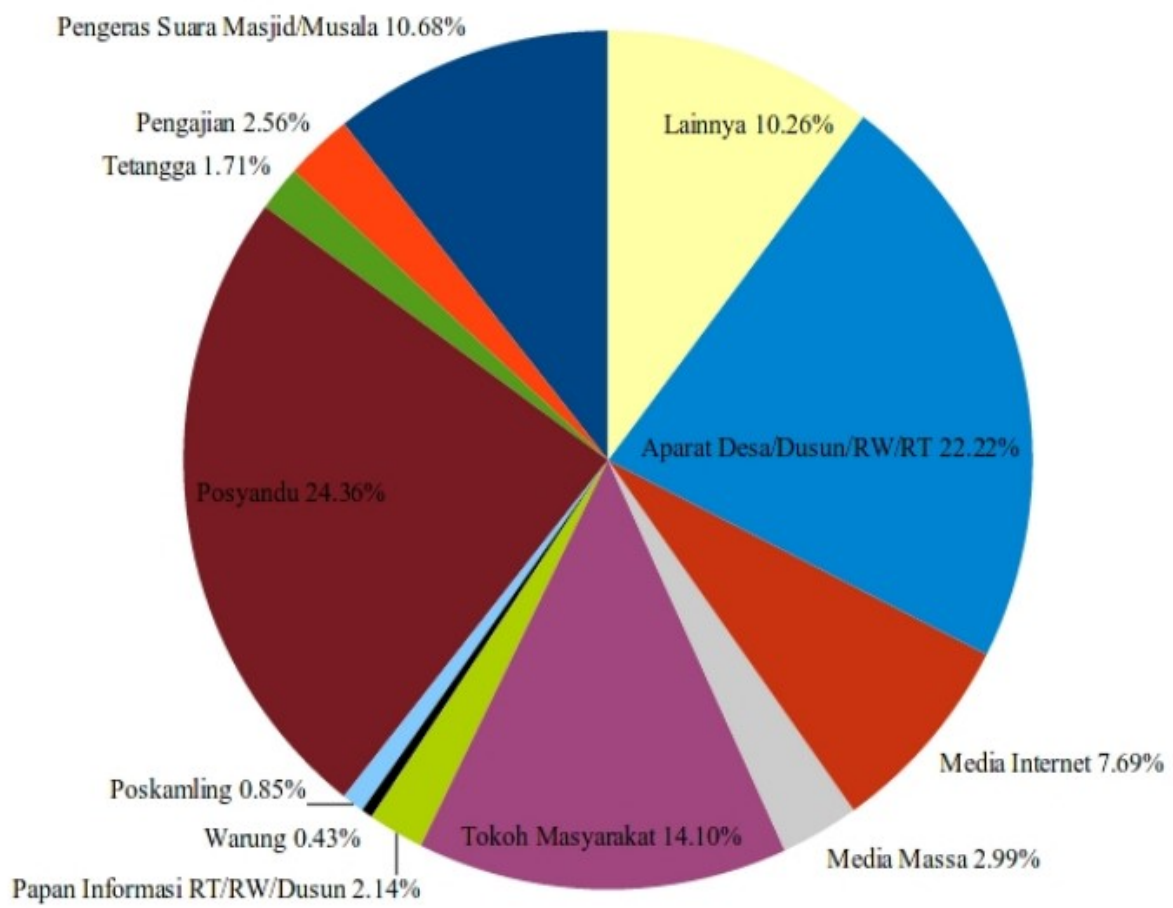

Gambar 3: Grafik Sumber Infomasi Kesehatan Masyarakat Cintaratu

Dari grafik pada Gambar 3 diketahui bahwa proporsi sumber informasi kesehatan terbesar adalah Posyandu diikuti oleh aparat desa/dusun/RW/RT. Desa Cintaratu memiliki lima dusun; setiap dusun memiliki 10 kader sehingga total terdapat 50 orang kader posyandu. Kader posyandu Cintaratu adalah wanita yang telah menikah, memiliki anak dan diberi tugas untuk membantu 
penyelenggaraan kegiatan kesehatan warga desa khususnya kesehatan ibu dan anak. Untuk memudahkan koordinasi maka dibentuk grup media perpesanan WhatsApp kader posyandu. Para kader tidak hanya menyalurkan informasi ketika kegiatan posyandu berjalan, namun informasi juga disalurkan secara informal melalui tausiah pengajian yang rutin dilakukan sekali seminggu.

Selain itu di Desa Cintaratu, informasi kesehatan diakses melalui berbagai media termasuk media massa dan media digital. Hanya 3\% dari informan yang menggunakan media massa (TV \& Radio) sebagai sumber informasi kesehatan. Dari hasil data survei (Tabel 1), media massa yang paling banyak digunakan oleh masyarakat Cintaratu adalah televisi sebesar $86,73 \%$, yaitu dengan frekuensi pemakaian rendah (15-235 menit per hari) 46,84\%, penggunaan sedang (236-470 menit dalam sehari) $48,10 \%$. Sementara itu hanya 5,06\% yang menggunakan televisi dengan frekuensi tinggi (471-720 menit per hari).

Tabel 1. Kepemilikan Media Masyarakat Desa Cintaratu

\begin{tabular}{|c|c|c|c|c|}
\hline \multirow{2}{*}{\multicolumn{2}{|c|}{ Media }} & \multicolumn{2}{|c|}{ Kepemilikan } & \multirow{3}{*}{$\begin{array}{c}\text { Total } \\
98\end{array}$} \\
\hline & & \multirow{2}{*}{$\begin{array}{c}\text { Memiliki } \\
85\end{array}$} & \multirow{2}{*}{$\begin{array}{c}\text { Tidak } \\
13\end{array}$} & \\
\hline & f & & & \\
\hline Televisi & $\%$ & 86.73 & 13.27 & 100 \\
\hline \multirow{2}{*}{ Radio } & f & 28 & 70 & 98 \\
\hline & $\%$ & 28.57 & 71.43 & 100 \\
\hline \multirow{2}{*}{$\begin{array}{l}\text { Surat } \\
\text { Kabar }\end{array}$} & $\bar{f}$ & 0 & 98 & 98 \\
\hline & $\%$ & 0 & 100 & 100 \\
\hline \multirow{2}{*}{ Internet } & $\mathbf{f}$ & 51 & 47 & 98 \\
\hline & $\%$ & 52.04 & 47.96 & 100 \\
\hline
\end{tabular}

Jika dibandingkan dengan konsumsi terhadap televisi, akses informasi kesehatan menggunakan internet juga terbilang kecil, hanya 7.70\%. Dari data statistik, Indonesia menduduki peringkat ke 4 dunia sebagai negara dengan pengguna internet terbanyak hingga Desember 2019 (InternetWorldStats.com, 2020). Ketika mengakses internet telah menjadi rutinitas bagi sebagian besar orang di Indonesia, ternyata hal tersebut tidak berlaku bagi masyarakat Desa Cintaratu. Dari hasil survei yang dilakukan di Cintaratu, hanya sekitar 52,04\% penduduk Cintaratu yang memiliki akses terhadap internet dengan intensitas penggunaan yang cenderung rendah (5-238 menit per hari) sebesar (68,89\%). Dengan memanfaatkan penggunaan media internet tersebut, hanya $31,03 \%$ dari $52.04 \%$ penduduk yang menggunakannya untuk mengakses informasi kesehatan.

Sumber informasi melalui opinion leader atau pemuka pendapat yang terdiri dari aparat desa/dusun/RW/RT juga cukup penting, karena dapat menyalurkan informasi langsung melalui pengajian atau ketika sedang ada hajatan di rumah-rumah warga. Di desa Cintaratu, apa yang diketahui oleh masyarakat masih tergantung pada adanya opinion leader ini. Opinion leader adalah individu atau organisasi terkenal yang memiliki kemampuan untuk mempengaruhi opini publik tentang suatu topik tertentu. Aparat desa/dusun/RW/RT, bidan dan kader-kadernya dianggap sebagai orang yang lebih tahu dan lebih paham tentang kesehatan, sehingga mereka menjadi tumpuan informasi kesehatan bagi masyarakat Cintaratu. 


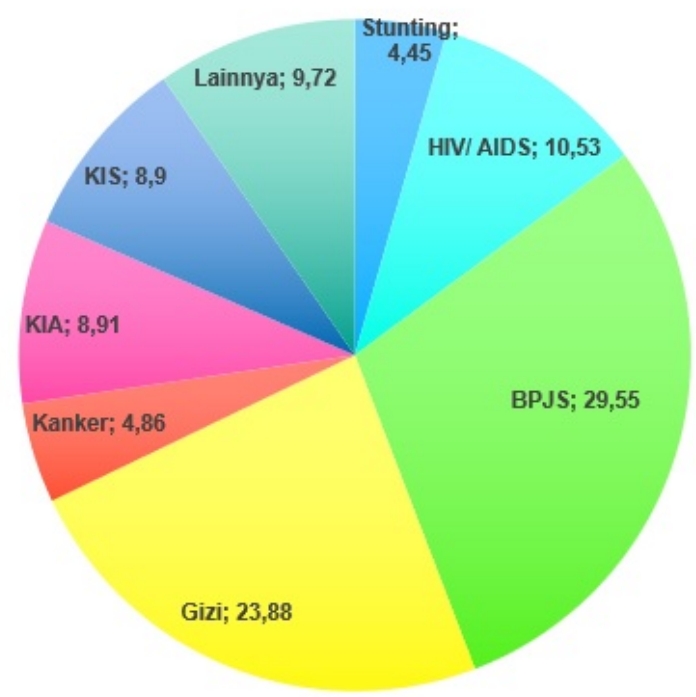

Gambar 4: Grafik Informasi Kesehatan dari opinion leader yang sering didengar di Cintaratu

Melalui data survei tentang informasi kesehatan dari opinion leader di Cintaratu (Gambar 4), diketahui bahwa informasi-informasi kesehatan yang paling sering didengar adalah menyoal BPJS secara umum (29,55\%), disusul informasi mengenai gizi $(23,88 \%)$, sedangkan informasi mengenai JKN-KIS PBI hanya berada pada angka 8,9\%. Angka ini terbilang kecil jika dibandingkan dengan kemampuan warga dalam mengakses internet.

Tabel 2. Perbedaan JKN-KIS PBI dan non-PBI yang diketahui oleh masyarakat Desa Cintaratu

\begin{tabular}{|l|l|}
\hline \multicolumn{1}{|c|}{ JKN-KIS PBI } & \multicolumn{1}{c|}{ JKN-KIS non-PBI } \\
\hline $\begin{array}{l}\text { Peserta berada di kelas III dan tidak dapat } \\
\text { naik ke kelas yang lebih tinggi }\end{array}$ & Peserta dapat memilih kelas I, II atau III \\
\hline $\begin{array}{l}\text { Peserta tidak dapat memilih faskes tingkat I } \\
\text { kecuali puskesmas kelurahan atau desa }\end{array}$ & $\begin{array}{l}\text { Peserta dapat memilih faskes tingkat I yang } \\
\text { telah ditentukan dan sudah bekerjasama } \\
\text { dengan BPJS sesuai dengan domisili }\end{array}$ \\
\hline Biaya iuran ditanggung oleh pemerintah & $\begin{array}{l}\text { Biaya iuran ditanggung sendiri atau oleh } \\
\text { instansi pemberi kerja }\end{array}$ \\
\hline
\end{tabular}

Apabila ditelusuri lebih lanjut berdasarkan hasil FGD dan observasi, masyarakat Desa Cintaratu yang menjadi penerima JKN-KIS PBI hanya mengetahui beberapa perbedaan serta kegunaan JKN-KIS PBI dibandingkan JKN-KIS non-PBI. Dari Tabel 2, dapat diketahui informasi apa saja yang dipahami masyarakat Desa Cintaratu terkait infomasi JKN-KIS PBI maupun non-PBI. Namun demikian, informasi inipun tidak menyebar secara merata. Beberapa warga mengetahui sebagian informasi saja dan sebagian warga lainnya mengetahui sisa informasi lainnya.

\section{Kesimpulan}

Distribusi informasi JKN-KIS PBI secara umum kurang transparan di Desa Cintaratu. Data yang digunakan sebagai dasar penetapan sesiapa saja yang menerima bantuan adalah data penduduk 
Desa Cintaratu tahun 1997. Data tersebut telah kedaluwarsa sehingga penerima bantuan menjadi tidak tepat sasaran. Beberapa penerima bantuan telah meninggal dan beberapa lainnya memiliki tingkat ekonomi yang lebih baik sehingga tidak masuk kriteria fakir miskin dan tidak layak menerima bantuan JKN-KIS PBI. Idealnya penggunaan data dasar bersifat bottom-up atau dari bawah ke atas. Desa dapat melakukan sensus mandiri dan menjadikan data tersebut sebagai acuan yang dapat disalurkan kepada pemerintah pusat.

Masyarakat Desa Cintaratu menggunakan berbagai macam media untuk mendapatkan informasi kesehatan, termasuk media massa dan media digital. Televisi menjadi media massa utama yang dimiliki oleh masyarakat desa, namun dari data survei, $F G D$, maupun observasi, didapat bahwa masyarakat Desa Cintaratu masih bergantung pada informasi yang bersifat tradisional, yaitu menjadikan opinion leader sebagai sumber informasi utama. Masyarakat Desa Cintaratu lebih percaya informasi kesehatan yang disampaikan oleh para opinion leader dibanding informasi melalui media massa maupun media digital. Jika pemerintah daerah atau pusat ingin melakukan sosialisasi mengenai kesehatan khususnya JKN-KIS PBI di Desa Cintaratu maka memanfaatkan opinion leader sebagai penyebar informasi adalah pilihan yang lebih baik daripada melalui media massa mainstream atau media digital.

\section{Pernyataan}

Penulis mengucapkan terima kasih kepada warga Desa Cintaratu (terutama warga Dusun Cintasari dan Dusun Bontos) dan Univesitas Padjadjaran yang telah membantu memfasilitasi kegiatan ini sehingga dapat berjalan lancar.

\section{Referensi}

Ardinata, M. (2020). Tanggung Jawab Negara terhadap Jaminan Kesehatan dalam Perspektif Hak $\begin{array}{llll}\text { Asasi Manusia (HAM). Jurnal } & \text { HAM, }\end{array}$ https://doi.org/10.30641/HAM.2020.11.319-332

Biro Komunikasi dan Pelayanan Masyarakat. (2019, July 16). Indeks Pembangunan Kesehatan Masyarakat Membaik Dalam 5 Tahun. Kementerian Kesehatan Republik Indonesia. https://www.kemkes.go.id/article/view/19071700001/indeks-pembangunan-kesehatanmasyarakat-membaik-dalam-5-tahun.html

Enceng. (2019, November 18). Warga Kabupaten Pangandaran yang Terdaftar Peserta BPJS Baru 284.444 Jiwa Harapan Rakyat Online. https://www.harapanrakyat.com/2019/11/warga-kabupaten-pangandaran-yang-terdaftarpeserta-bpjs/

Fuady, I., Arifin, H. S., \& Prasanti, D. (2017). Literasi Informasi Kesehatan: Penyuluhan Informasi Pencegahan HIV AIDS Bagi Masyarakat di Kawasan Wisata Pangandaran. Dharmakarya, 6(1), 62-65. https://doi.org/10.24198/DHARMAKARYA.V6I1.14808

Hasanah, H. (2017). Teknik-Teknik Observasi (Sebuah Alternatif Metode Pengumpulan Data Kualitatif Ilmu-ilmu Sosial). At-Taqaddum, 8(1), 21-46. https://doi.org/10.21580/AT.V8I1.1163

Humas BPJS. (2020, July 3). Masuki Semester II Tahun 2020, BPJS Kesehatan Tuntas Bayar Seluruh Klaim RS. Bpjs-Kesehatan.Go.Id. https://bpjs- 
kesehatan.go.id/bpjs/post/read/2020/1588/Masuki-Semester-II-Tahun-2020-BPJSKesehatan-Tuntas-Bayar-Seluruh-Klaim-RS

InternetWorldStats.com. (2020). Internet Top 20 Countries - Internet World Users. https://www.internetworldstats.com/top20.htm

JKN.kemkes.go.id. (n.d.). Jaminan Kesehatan Nasional - FAQ. Retrieved July 25, 2021, from http://www.jkn.kemkes.go.id/detailfaq.php?id=9

Johnson, J. M. (1975). Doing field research. Free Press.

Mahendradhata, Y., Trisnantoro, L., Listyadewi, S., Soewondo, P., Marthias, T., Harimurti, P., \& Prawira, J. (2017). The Republic of Indonesia Health System Review, Health Systems in Transition, Vol-7 No.1. https://apps.who.int/iris/handle/10665/254716

Marekan, M., \& Ansori, T. (2019). Peran Dana Desa Dalam Memberdayakan Masyarakat Ditinjau Dari Perspektif Ekonomi Islam Study Di Desa Galak Kec. Slahung Kab. Ponorogo. JCD: Journal of Community Development and Disaster Management, 1(2), 117-128. https://ejournal.insuriponorogo.ac.id/index.php/jcd/article/view/743

Mustikasari, R. (2019). Indikator Kesejahteraan Rakyat Kabupaten Pangandaran 2019.

Paramita, A., \& Kristiana, L. (2013). Teknik Focus Group Discussion dalam Penelitian Kualitatif. Buletin Penelitian Sistem Kesehatan, 16(2). https://doi.org/10.22435/BPSK.V16I2

Rahman, F., \& Herwiningsih, S. (2021). Sosialisasi dan Pendampingan Posyandu Kemboja Kelurahan Tasikmadu Kota Malang dalam Mencegah Stunting. RESWARA: Jurnal $\begin{array}{llll}\text { Pengabdian Kepada } \quad \text { Masyarakat, } & \text { 307-312. }\end{array}$ https://doi.org/10.46576/RJPKM.V2I2.1124

Santana K, S. (2007). Menulis ilmiah: metode penelitian kualitatif. Yayasan Obor Indonesia.

Sekretariat Jenderal Kemenkes RI. (2018). Kementerian Kesehatan Bekerja: Laporan Kinerja 2015-2017. Kementerian Kesehatan RI. 